\title{
TALAJLAKÓ MEZOFAUNA (COLLEMBOLA) VIZSGÁLATOK A LAJTA PROJECT TERÜLETÉN
}

\author{
Winkler Dániel \& Traser György \\ Soproni Egyetem, Vadgazdálkodási és Gerinces Állattani Intézet \\ University of Sopron, Institute of Wildlife Management and Vertebrate Zoology \\ H-9400 Sopron, Bajcsy-Zs u. 4., Hungary \\ e-mail: winkler.daniel@uni-sopron.hu
}

\begin{abstract}
WINKLER D. \& TRASER GY.: STUDY ON SOIL MESOFAUNA IN THE LAJTA PROJECT. Hungarian Small Game Bulletin 13: 213-224. http://dx.doi.org/10.17243/mavk.2017.213

Collembola communities were studied in different agricultural habitats including intensively managed plant cultures, shelterbelts and grassy embankments in the area of the LAJTA Project. A total of 62 species were collected during the eleven-year study period (2002-2012). Three species, namely Axenyllodes bayeri, Metaphorura denisi and Pseudosinella aelleni have proven to be new to the Hungarian fauna. Collembola species richness, abundance and diversity were the highest in shelterbelts, which shows their ecological role in agricultural environments. Grassy embankments are further important ecotone habitats that play significant role in soil fauna diversity and abundance. Intensively managed monocultures (maize, summer rape and winter wheat) were characterized by Collembola communities with low species richness and abundance.
\end{abstract}

KULCSZAVAK: ugróvillás, agrárélőhely, szegély ökotonok

KEY WORDS: Collembola, agrohabitat, edge ecotones

\section{BEVEZETÉS}

Az ugróvillások úgynevezett elsődlegesen szárnyatlan (Apterygota), belső szájszervü (Entognatha) rovarok. Régebben „ősrovaroknak”, a mai „modern” rovarok ősének gondolták ezt a csoportot, de mostani tudásunk szerint inkább egy különálló fejlődési csoportot, a „Parainsecta”-t reprezentálják a hajnalrovarokkal (Protura) és a lábaspotrohúakkal (Diplura) közösen. Vizsgálatunkat a LAJTA Projecten belül nem az indokolja, hogy közvetlen kapcsolatban állnak az ottani szárnyas apróvad (pl. fogoly, fácán) állományaival, hanem az, hogy az ugróvillások a szárazföldi ökoszisztémák leggyakoribb rovarai (hivatkozás). Átlagos szabályként mondhatjuk, hogy zavartalan, természet közeli élőhelyeken 1000 példányuk él minden liter földben (hivatkozás). A mezofauna tagjaként közvetett jelentőségük a fogolypopulációra éppen óriási egyedszámukból következik: nevezetesen a táplálkozási piramis alján, gyakorlatilag minden, a fogoly számára is fontos ragadozó ízeltlábúnak (farkaspókok, futóbogarak, százlábúak) zsákmányállatát képezik. Így biztosan állíthatjuk, hogy ahol gazdag ugróvillás-közösség él, ott gazdag macrofauna és bő táplálékkínálat van a rovarevő fajok számára is. Mindezen túl az ugróvillások tevékenysége a holt szerves anyag fogyasztása, lebontása, valamint a talajflóra megfelelő baktérium-gomba arányának kialakításában jelentős. 
A mezőgazdasági művelés alatt álló területeken a talajdegradáció számos formája jelentkezik (talajtömörödés, szerkezeti degradáció, szerves anyag csökkenés, kemikáliák által okozott terhelés), ami visszatükröződik az ugróvillások abundanciájában és diverzitásában is (GILLER et al., 1997; SOUSA et al., 2006, FlOHRE at al. 2011, PAUL et al. 2011). A LAJTA Projectben végzett vizsgálataink elsődleges célja a faunisztikai feltárás mellett az eltérö intenzitással kezelt mezőgazdasági kultúrák, valamint ökotonok Collembola közösségeinek összehasonlító értékelése volt.

\section{ANYAG ÉS MÓDSZER}

A LAJTA Projectben 2002 és 2012 között végeztünk talajfaunisztikai vizsgálatokat. Összesen hat élöhelytípusban (erdősáv, árokpart/táblaszegély, repce, kukorica, őszi búza) vizsgáltuk az ugróvillás közösségek faunisztikai összetételét és mennyiségi viszonyait.

A kvantitatív elemzésekhez összesen 200 talajmintát vettünk egy $100 \mathrm{~cm}^{3}$ térfogatú, hossztengelyében két palástra osztott fémhenger segítségével. A begyüjtött talajmintákat még a gyüjtés napján papírtölcséres futtatóra (BALOGH, 1958) helyeztük. Két hét elteltével az ugróvillás egyedek leválogatása és mikroszkópos határozása következett.

Az ugróvillások (Collembola) határozása elsősorban GISIN (1960), STACH (1960, 1963), Massoud (1967), Deharveng (1982), FJellberg (1980, 1998), BABENKo et al. (1994), ZIMDARS \& DUNGER (1994), WEINER (1996), JORDANA et al. (1997), POMORSKI (1998), BRETFELD (1999), POTAPOW (2001) és THIBAUD et al. (2004) munkái segítségével történt. Az ugróvillások rendszertani áttekintésénél - kisebb változtatásokkal - a hazai fauna check-lista beosztását (DÁNYI \& TRASER 2008) vettük alapul.

A közösségi-ökológiai elemzés során a fajgazdagság, abundancia- és dominanciaviszonyok, fontosabb közösségi paraméterek (diverzitás, kiegyenlítettség) valamint hasonlósági indexek (Bray-Curtis) segítségével az egyes habitatok összehasonlító értékelését végeztük el.

\section{EREDMÉNYEK ÉS MEGVITATÁS}

\subsection{A LAJTA PROJECT UGRÓVILLÁSAINAK FAUNISZTIKAI ÉRTÉKELÉSE}

A gyüjtött 62 faj (összesen 9259 egyed) 14 családot képvisel (1. ábra). Legnagyobb egyedszámmal $(2603-28,11 \%)$ a Hypogastruridae család volt képviselt, összesen 9 fajuk fordult elö a vizsgálati területen. A tipikusan euedafikus fajokat magába foglaló Tullbergiidae család összesen 10 faja került elö, magas összegyedszámmal (2332 - 25,19\%). Ugyancsak magas összegyedszámmal (2042 - 22,05\%) képviselt a föként hemiedafikus fajokat magába foglaló Isotomidae család. Az Entomobryidae család magasabb fajszámmal, viszont jóval alacsonyabb egyedszámmal $(762-8,23 \%)$ volt jelen a minták összességét tekintve. Ennek többek közt az lehet a magyarázata, hogy egyes, föként a felszínen mozgó fajok (Lepidocyrtus spp., Willowsia spp. Orchesella spp.) a mintavételi módszer miatt alulreprezentáltak. Kis egyedszámmal, több esetben érdekes fajokkal további családok is képviselve voltak a mintákban (Neanuridae, Odontellidae, Onychiuridae, Cyphoderidae család fajai, valamint a Neelidae, Arrhopalitidae, Sminthurididae, Katiannidae, Sminthuridae, Bourletiellidae család úgynevezett gömböc ugróvillásai). 


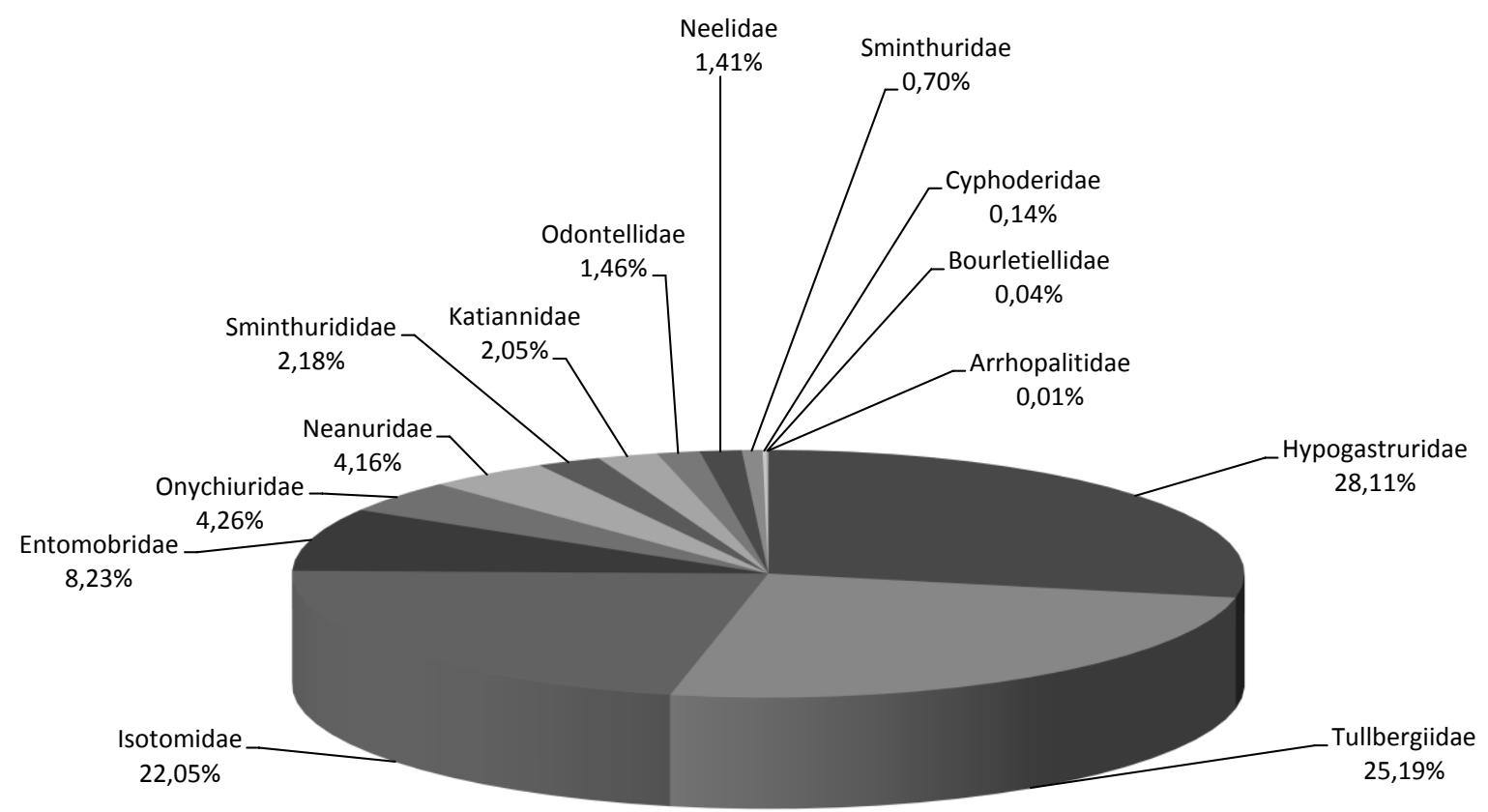

1. ábra: A gyüjtött ugróvillás egyedek családok szerinti megoszlása Figure 1.: Proportional distribution of Collembola families

A LAJTA Project területén gyüjtött fajok listáját az alábbiakban tesszük közzé. Néhány jellegzetes ugróvillás-faj habitusképét a 2 . ábra szemlélteti.

\section{A LAJTA Project keretében gyüjtött ugróvillások rendszertani áttekintése:}

\section{PODUROMORPHA Börner, 1913}

\section{Hypogastruridae Börner, 1906}

Hypogastrura manubrialis (Tullberg, 1869)

Hypogastrura socialis (Uzel, 1890)

Hypogastrura vernalis (Carl, 1901)

Ceratophysella denticulata (Bagnall, 1941)

Ceratophysella succinea (Gisin, 1949)

Schoettella ununguiculata (Tullberg, 1869)

Willemia intermedia Mills, 1934

Willemia virae Kaprus, 1997

Xenylla grisea Axelson, 1900

\section{Odontellidae Massoud, 1967}

Axenyllodes bayeri (Kseneman, 1935)

\section{Neanuridae Tullberg, 1871}

Friesea afurcata (Denis, 1926)

Micranurida pygmaea Börner, 1901

Pseudachorutes dubius Krausbauer, 1898

Pseudachorutes parvulus Börner, 1901

Pseudachorutes pratensis Rusek, 1973 


\section{Onychiuridae Börner, 1901}

Protaphorura armata (Tullberg, 1869)

Protaphorura tricampata (Gisin, 1956)

\section{Tullbergiidae Bagnall, 1935}

Doutnacia xerophila Rusek, 1974

Mesaphorura critica Ellis, 1976

Mesaphorura hylophila Rusek, 1982

Mesaphorura italica (Rusek, 1971)

Mesaphorura krausbaueri Börner, 1901

Mesaphorura macrochaeta Rusek, 1976

Mesaphorura sylvatica (Rusek, 1971)

Mesaphorura yosii (Rusek, 1967)

Metaphorura affinis (Börner, 1902)

Metaphorura denisi Simon, 1985

\section{ENTOMOBRYOMORPHA Börner, 1913}

\section{Isotomidae Börner, 1913}

Cryptopygus thermophilus (Axelson, 1900)

Folsomides parvulus Stach, 1922

Isotomodes productus (Axelson, 1906)

Proisotoma minuta (Tullberg, 1871)

Isotoma anglicana Lubbock, 1862

Isotoma viridis Bourlet, 1839

Parisotoma notabilis (Schäffer, 1896)

Isotomiella minor (Schäffer, 1896)

Isotomurus palustris (Müller, 1776)

\section{Entomobridae Schött, 1891}

Entomobrya lanuginosa (Nicolet, 1841)

Entomobrya multifasciata (Tullberg, 1871)

Orchesella albofasciata Stach, 1960

Orchesella cincta (Linnaeus, 1758)

Lepidocyrtus cf. lignorum (Fabricius, 1793)

Lepidocyrtus paradoxus Uzel, 1890

Heteromurus major (Moniez, 1889)

Willowsia buski (Lubbock, 1871)

Willowsia nigromaculata (Lubbock, 1873)

Pseudosinella aelleni da Gama 1973

Pseudosinella alba (Packard, 1873)

Pseudosinella octopunctata Börner, 1901

Pseudosinella petterseni Börner, 1901

Pseudosinella sexoculata Schött, 1902

Pseudosinella zygophora (Schille, 1908)

\section{Cyphoderidae Börner, 1913}

Cyphoderus albinus Nicolet, 1842

Cyphoderus bidenticulatus Parona, 1888 


\section{NEELIPLEONA Moen et Ellis, 1984}

\section{Neelidae Folsom, 1896}

Megalothorax minimus Willem, 1900

a

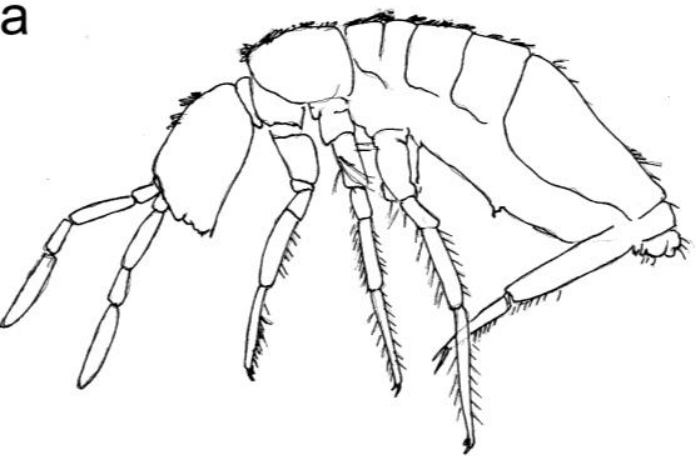

b
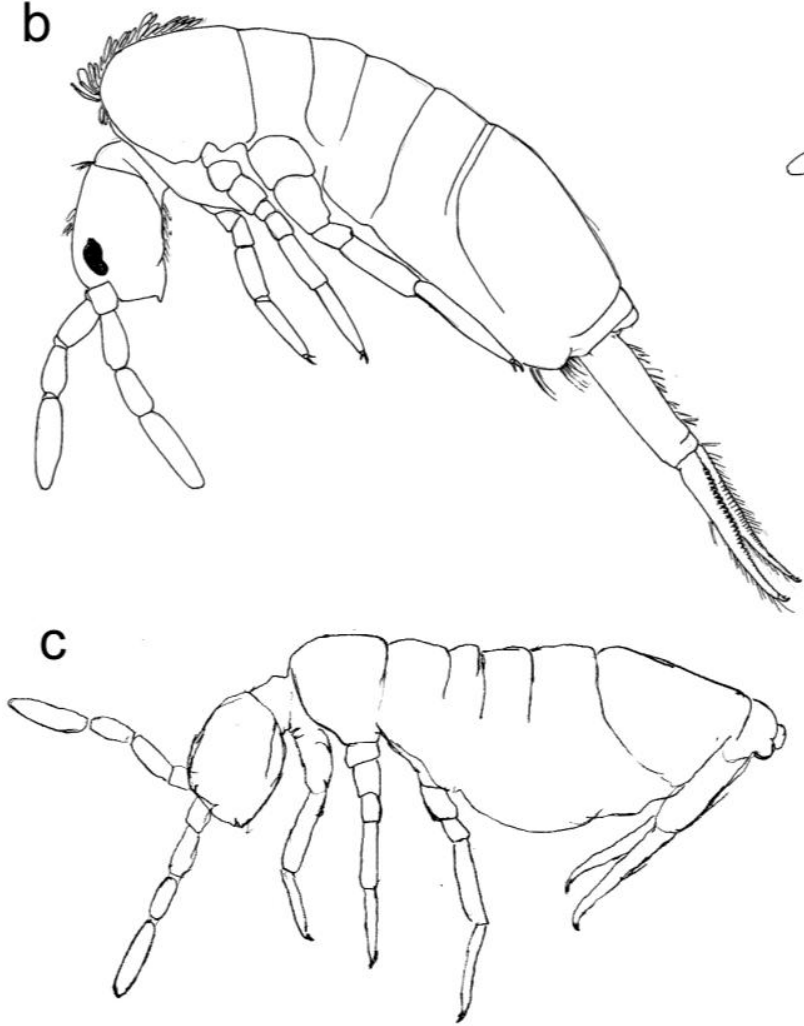

d

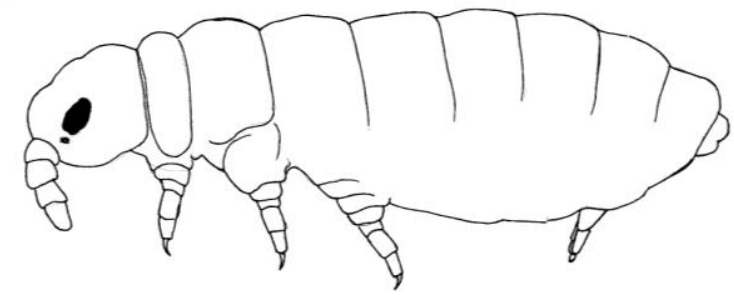

e
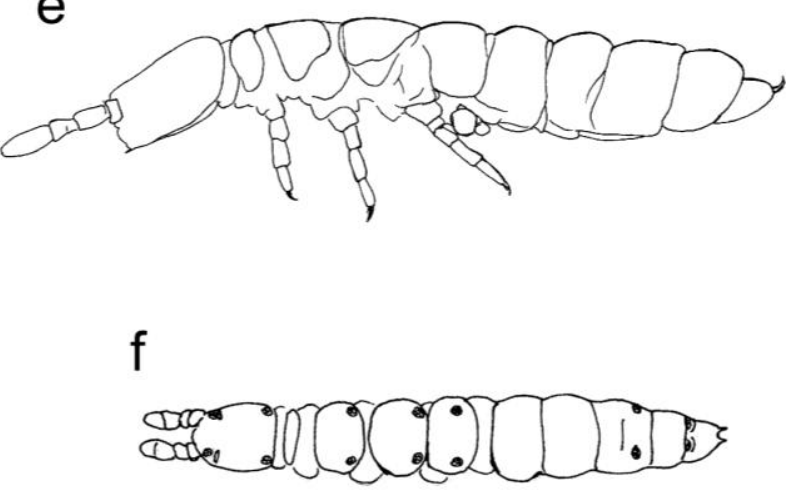

g

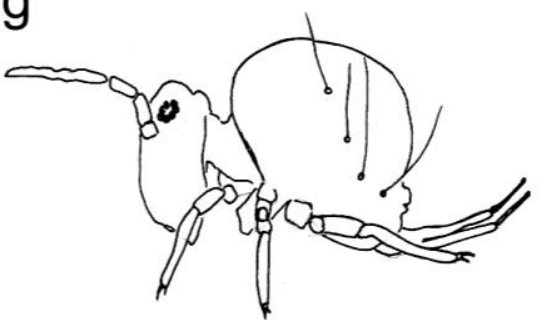

2. ábra: A LAJTA Projectben gyüjtött néhány jellegzetes Collembola faj habitusképe Figure 2: Habitus of some representative Collembola species collected in the LAJTA Project

a. Cyphoderus bidenticulatus; $b$. Lepidocyrtus lignorum; $c$. Pseudosinella aelleni; d. Pseudachorutes dubius; . Protaphorura armata; f. Mesaphorura krausbaueri; g. Sphaeridia pumilis 


\section{SYMPHYPLEONA Börner, 1901}

\section{Arrhopalitidae Stach, 1956}

Arrhopalites sp.

\section{Sminthurididae Börner, 1906}

Sphaeridia pumilis (Krausbauer, 1898)

\section{Katiannidae Börner, 1913}

Sminthurinus aureus (Lubbock, 1862)

Sminthurinus elegans (Fitch, 1863)

\section{Sminthuridae Lubbock, 1862}

Sminthurus nigromaculatus Tullberg, 1871

Sminthurus viridis (Linnaeus, 1758)

\section{Bourletiellidae Börner, 1913}

Deuterosminthurus bicinctus Koch, 1840

Heterosminthurus bilineatus (Bourlet, 1842)

A gyüjtések során három olyan faj is előkerült, amely új a hazai Collembola faunára nézve. Az Odontellidae családba tartozó Axenyllodes bayeri-t a legtöbb szomszédos országban megtalálták már, így felbukkanása hazánkban is várható volt. A Tullbergiidae családba tartozó, mediterrán elterjedésű Metaphorura denisi eddig csak Kréta szigetéről, Bulgáriából, Franciaországból és az Ibériai-félszigetről került elő. A LAJTA Project területén nagy számban a mezőgazdasági táblákat elválasztó szegélyekben, száraz árokpartok rézsüjében találtuk, de előkerült még akácos erdősáv, valamint őszi búza talajából is. Az Entomobryidae családba tartozó Pseudosinella aelleni eddig a szomszédos Ausztriából valamint Németországból került még csak elő, az erdősávokban 8 egyedét gyüjtöttük.

\subsection{A LAJTA PROJECT UGRÓVILLÁSAINAK KÖZÖSSÉG-ÖKOLÓGIAI ÉRTÉKELÉSE}

A vizsgált vetésterületek és szegélyélöhelyek (ökotonok) talajzoológiai felvételezése során nyert ugróvillások abundancia értékeit a 1. táblázat tartalmazza, míg a fontosabb közösségiparamétereket a 2. táblázat foglalja össze.

Fajban a leggazdagabb ugróvillás-közösséget az erdősávok talajában találtunk, ahol összesen 46 faj 3849 egyedét gyüjtöttük.

A várakozásnak megfelelően a diverzitás mérőszámai is ebben a habitatban adódtak magasnak, ami hangsúlyozza az erdősávok agrárkörnyezetben betöltött fontos szerepét talajfaunisztikai vonatkozásban is. Az erdősávokban gyüjtött ugróvillások közel egyharmada az Isotomidae család fajai közül került ki. A dominancia-struktúra (3. ábra) kiegyenlített. A közösség domináns fajai (>10\%) a Parisotoma notabilis és a Metaphorura affinis.

A vetésterületek közül a repce kultúrában gyüjtött talajminták ugróvillás-abundanciája volt a legmagasabb, viszont a diverzitási és kiegyenlítettségi mutatók ennél a Collembola közösségnél a legalacsonyabbak. Összesen 8 család 22 faját sikerült kimutatni. Az ugróvillásegyedek több mint fele a Hypogastruridae családból került ki, de magas százalékos aránnyal 
1. táblázat: A vizsgált élőhelyeken előforduló Collembola fajok egyedszámai

Table 1: Collembola species spectrum and abundance in the sampled habitats

\begin{tabular}{|c|c|c|c|c|c|c|}
\hline $\begin{array}{c}\text { Collembola fajok } \\
\text { Species }\end{array}$ & $\begin{array}{c}\text { Erdősáv } \\
\text { Shelterbelt }\end{array}$ & $\begin{array}{l}\text { Repce } \\
\text { Rape }\end{array}$ & $\begin{array}{c}\text { Kukorica } \\
\text { Maize }\end{array}$ & $\begin{array}{c}\text { Öszi búza } \\
\text { Winter wheat }\end{array}$ & $\begin{array}{c}\text { Árokpart } \\
\text { Embankment }\end{array}$ & $\Sigma$ \\
\hline Hypogastrura manubrialis & 28 & 0 & 0 & 0 & 0 & 28 \\
\hline Hypogastrura socialis & 0 & 0 & 0 & 44 & 577 & 621 \\
\hline Hypogastrura vernalis & 0 & 74 & 17 & 17 & 0 & 108 \\
\hline Ceratophysella denticulata & 8 & 1 & 98 & 1 & 0 & 108 \\
\hline Ceratophysella succinea & 0 & 992 & 0 & 126 & 0 & 1118 \\
\hline Schoettella ununguiculata & 374 & 0 & 0 & 0 & 0 & 374 \\
\hline Willemia intermedia & 9 & 3 & 0 & 5 & 0 & 17 \\
\hline Willemia virae & 130 & 34 & 28 & 7 & 28 & 227 \\
\hline Xenylla grisea & 2 & 0 & 0 & 0 & 0 & 2 \\
\hline Axenyllodes bayeri & 13 & 0 & 0 & 0 & 122 & 135 \\
\hline Friesea afurcata & 0 & 0 & 9 & 19 & 0 & 28 \\
\hline Micranurida pygmaea & 98 & 0 & 0 & 0 & 2 & 100 \\
\hline Pseudachorutes dubius & 5 & 0 & 0 & 0 & 0 & 5 \\
\hline Pseudachorutes parvulus & 160 & 0 & 0 & 0 & 13 & 173 \\
\hline Pseudachorutes pratensis & 76 & 0 & 0 & 0 & 3 & 79 \\
\hline Protaphorura armata & 357 & 18 & 2 & 7 & 3 & 387 \\
\hline Protaphorura tricampata & 7 & 0 & 0 & 0 & 0 & 7 \\
\hline Doutnacia xerophyla & 133 & 3 & 0 & 0 & 11 & 147 \\
\hline Mesaphorura critica & 4 & 8 & 6 & 8 & 35 & 61 \\
\hline Mesaphorura hilophila & 2 & 0 & 0 & 4 & 0 & 6 \\
\hline Mesaphorura italica & 6 & 7 & 0 & 9 & 0 & 22 \\
\hline Mesaphorura krausbaueri & 44 & 0 & 0 & 0 & 78 & 122 \\
\hline Mesaphorura macrochaeta & 0 & 0 & 0 & 11 & 0 & 11 \\
\hline Mesaphorura sylvatica & 1 & 0 & 0 & 0 & 0 & 1 \\
\hline Mesaphorura yosii & 0 & 7 & 2 & 0 & 0 & 9 \\
\hline Metaphorura affinis & 660 & 0 & 0 & 0 & 0 & 660 \\
\hline Metaphorura denisi & 9 & 0 & 0 & 10 & 1274 & 1293 \\
\hline Cryptopygus thermophilus & 0 & 0 & 0 & 0 & 54 & 54 \\
\hline Folsomides parvulus & 63 & 21 & 0 & 2 & 54 & 140 \\
\hline Isotomodes productus & 0 & 0 & 0 & 0 & 70 & 70 \\
\hline Proisotoma minuta & 1 & 0 & 0 & 0 & 0 & 1 \\
\hline Isotoma anglicana & 0 & 0 & 0 & 4 & 0 & 4 \\
\hline Isotoma viridis & 15 & 0 & 0 & 0 & 31 & 46 \\
\hline Parisotoma notabilis & 777 & 577 & 27 & 27 & 71 & 1479 \\
\hline Isotomiella minor & 220 & 0 & 0 & 1 & 20 & 241 \\
\hline Isotomurus palustris & 7 & 0 & 0 & 0 & 0 & 7 \\
\hline Entomobrya lanuginosa & 3 & 35 & 2 & 6 & 5 & 51 \\
\hline Entomobrya multifasciata & 119 & 2 & 1 & 0 & 9 & 131 \\
\hline Orchesella albofasciata & 16 & 0 & 0 & 0 & 0 & 16 \\
\hline Orchesella cincta & 64 & 10 & 0 & 0 & 7 & 81 \\
\hline Lepidocyrtus cf. lignorum & 10 & 0 & 0 & 0 & 0 & 10 \\
\hline Lepidocyrtus paradoxus & 0 & 0 & 0 & 0 & 1 & 1 \\
\hline Heteromurus major & 4 & 0 & 0 & 1 & 12 & 17 \\
\hline
\end{tabular}


Az 1. táblázat folytatása - Table 1 cont.

\begin{tabular}{|c|c|c|c|c|c|c|}
\hline $\begin{array}{c}\text { Collembola fajok } \\
\text { Species }\end{array}$ & $\begin{array}{c}\text { Erdősáv } \\
\text { Shelterbelt }\end{array}$ & $\begin{array}{l}\text { Repce } \\
\text { Rape }\end{array}$ & $\begin{array}{c}\text { Kukorica } \\
\text { Maize }\end{array}$ & $\begin{array}{c}\text { Öszi búza } \\
\text { Winter wheat }\end{array}$ & $\begin{array}{c}\text { Árokpart } \\
\text { Embankment }\end{array}$ & $\Sigma$ \\
\hline Willowsia buski & 13 & 0 & 0 & 0 & 14 & 27 \\
\hline Willowsia nigromaculata & 1 & 0 & 0 & 0 & 0 & 1 \\
\hline Pseudosinella aelleni & 8 & 0 & 0 & 0 & 5 & 13 \\
\hline Pseudosinella alba & 135 & 52 & 11 & 15 & 46 & 259 \\
\hline Pseudosinella octopunctata & 9 & 26 & 0 & 14 & 38 & 87 \\
\hline Pseudosinella petterseni & 1 & 6 & 2 & 0 & 18 & 27 \\
\hline Pseudosinella sexoculata & 0 & 3 & 0 & 0 & 0 & 3 \\
\hline Pseudosinella zygophora & 16 & 0 & 6 & 0 & 16 & 38 \\
\hline Cyphoderus albinus & 6 & 0 & 0 & 0 & 5 & 11 \\
\hline Cxphoderus bidenticulatus & 2 & 0 & 0 & 0 & 0 & 2 \\
\hline Megalothorax minimus & 115 & 3 & 1 & 3 & 9 & 131 \\
\hline Sphaeridia pumilis & 93 & 0 & 0 & 43 & 66 & 202 \\
\hline Sminthurinus aureus & 0 & 172 & 0 & 1 & 1 & 174 \\
\hline Sminthurinus elegans & 0 & 0 & 0 & 0 & 16 & 16 \\
\hline Sminthurus nigromaculatus & 0 & 0 & 0 & 0 & 3 & 3 \\
\hline Sminthurus viridis & 22 & 1 & 0 & 2 & 37 & 62 \\
\hline Deuterosminthurus bicinctus & 0 & 0 & 0 & 0 & 1 & 1 \\
\hline Heterosminthurus bilineatus & 3 & 0 & 0 & 0 & 0 & 3 \\
\hline Arrhopalites sp. & 0 & 0 & 0 & 0 & 1 & 1 \\
\hline$\Sigma$ & 3849 & 2055 & 212 & 387 & 2756 & 9259 \\
\hline
\end{tabular}

2. táblázat: A vizsgált habitatok Collembola-közösségeinek paraméterei

Table 2: Ecological structural properties of Collembola communities of the sampled agro-habitats

\begin{tabular}{|c|c|c|c|c|c|}
\hline & $\begin{array}{l}\text { Fajszám (S) } \\
\text { Species } \\
\text { richness }(S)\end{array}$ & $\begin{array}{c}\text { Egyedszám (N) } \\
\text { Number of } \\
\text { individuals }(N)\end{array}$ & $\begin{array}{c}\text { Simpson } \\
\text { diverzitás (D) } \\
\text { Simpson's } \\
\text { diversity }(D)\end{array}$ & $\begin{array}{c}\text { Shannon } \\
\text { diverzitás }\left(\mathbf{H}^{\prime}\right) \\
\text { Shannon diversity } \\
\left(H^{\prime}\right)\end{array}$ & $\begin{array}{c}\text { Egyenletesség } \\
(\mathbf{J}) \\
\text { Equitability }(J)\end{array}$ \\
\hline $\begin{array}{c}\text { Erdősáv } \\
\text { Shelterbelt }\end{array}$ & 46 & 3849 & 0,899 & 2,728 & 0,713 \\
\hline $\begin{array}{l}\text { Repce } \\
\text { Rape }\end{array}$ & 22 & 2055 & 0,678 & 1,565 & 0,506 \\
\hline $\begin{array}{l}\text { Kukorica } \\
\text { Maize }\end{array}$ & 14 & 212 & 0,740 & 1,805 & 0,684 \\
\hline $\begin{array}{c}\text { Öszi búza } \\
\text { Winter wheat }\end{array}$ & 25 & 387 & 0,853 & 2,451 & 0,762 \\
\hline $\begin{array}{c}\text { Árokpart } \\
\text { Embankment }\end{array}$ & 37 & 2756 & 0,736 & 2,044 & 0,566 \\
\hline
\end{tabular}

( $30 \%)$ képviselt az Isotomidae család is. A dominancia-görbe meredek lefutású (4. ábra), ami jelzi a közösség alacsony kiegyenlítettségét is. Eudomináns fajok a Ceratophysella succinea és a Parisotoma notabilis.

A legalacsonyabb faj- és egyedszámú ugróvillás-közösség a kukorica kultúra talajára volt jellemző. Mindössze 14 faj 212 egyede került elő, amely 7 Collembola családot képvisel. Az ugróvillás egyedek több mint kétharmada a Hypogastruridae család fajai közül került ki. 


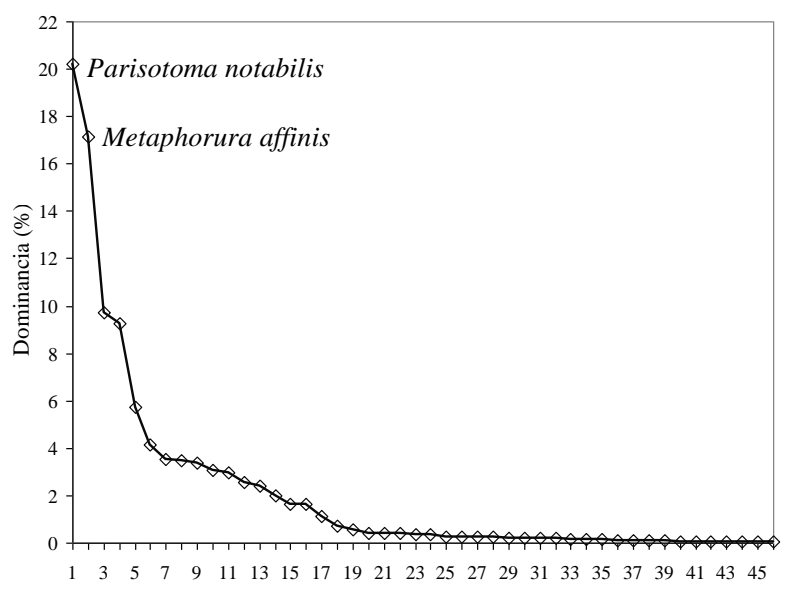

3. ábra: Az erdősávok Collembolaközösségének dominanciagörbéje

Figure 3: Dominance structure of the Collembola communities of shelterbelts

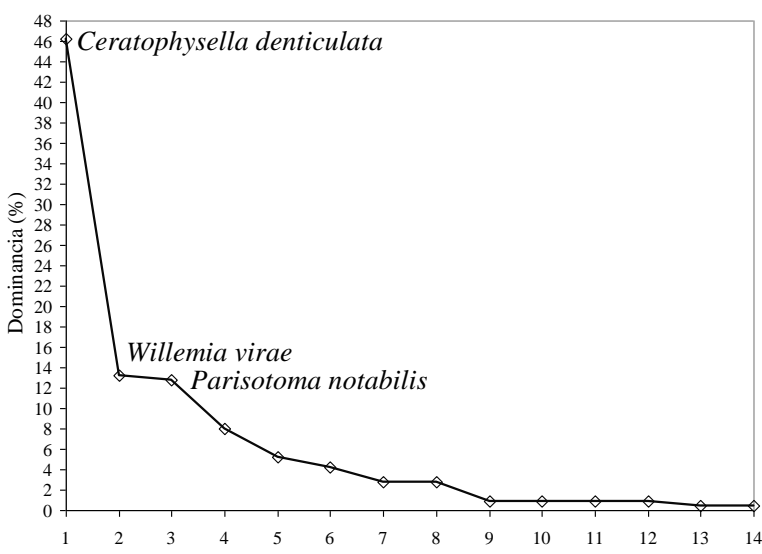

5. ábra. A kukorica kultúrák Collembolaközösségének dominanciagörbéje

Figure 5: Dominance structure of the Collembola communities of maize fields

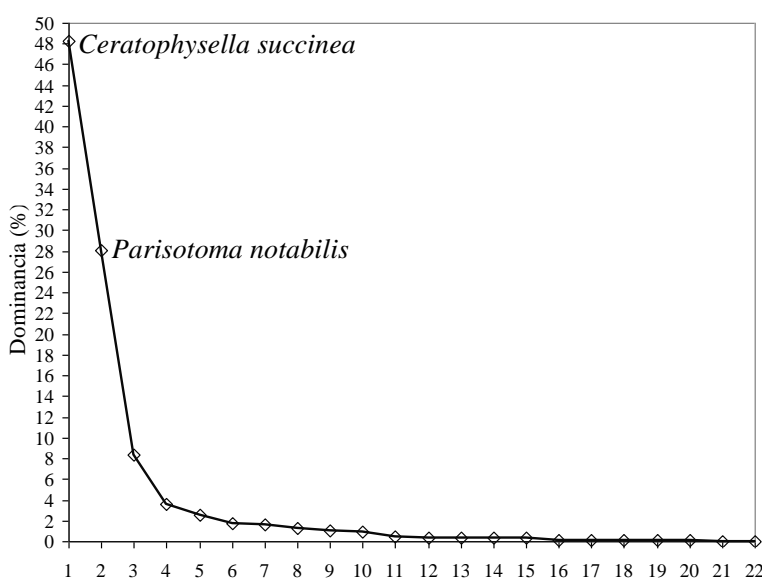

4. ábra: A repcekultúrák Collembolaközösségének dominanciagörbéje

Figure 4: Dominance structure of the Collembola communities of rape fields

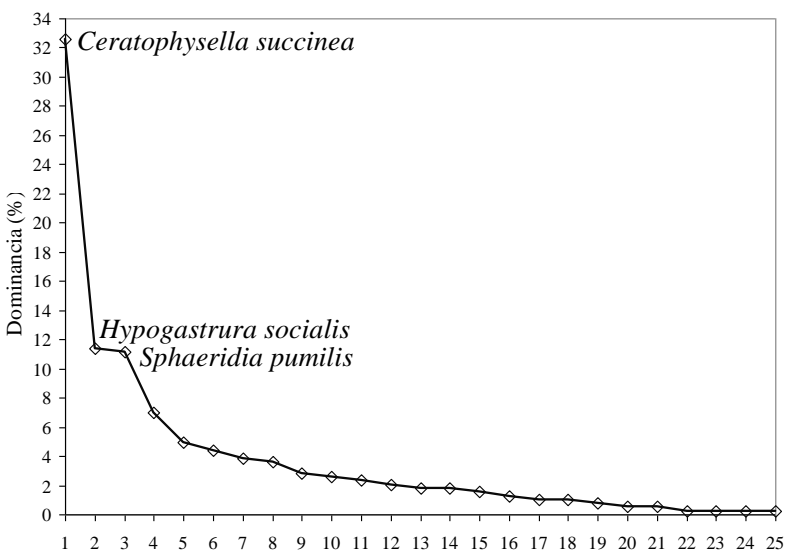

6. ábra. Az őszibúza-kultúrák Collembolaközösségének dominanciagörbéje

Figure 6: Dominance structure of the Collembola communities of winter wheat fields

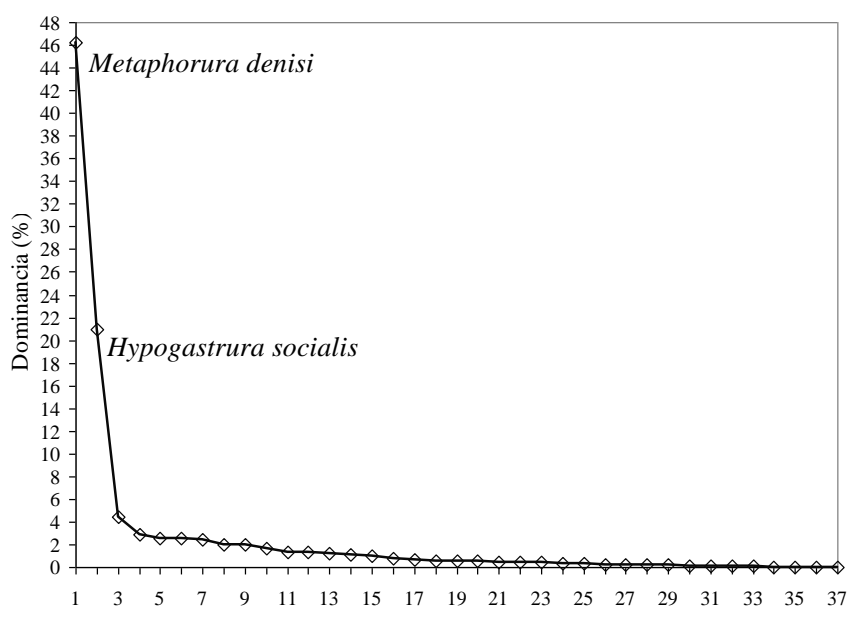

7. ábra. Az árokpart-táblaszegély ökotonok Collembola-közösségének dominancia-görbéje

Figure 7: Dominance structure of the Collembola communities of embankments 
A diverzitás és kiegyenlítettség a repce kultúrák ugróvillás-közösségéhez hasonlóan itt is alacsony. Eudomináns faj a Ceratophysella denticulata, domináns fajok a Willemia virae és a Parisotoma notabilis (5. ábra).

A három vizsgált termesztett növénykultúra közül az őszi búza talajában találtuk a legdiverzebb ugróvillás-közösséget. Összesen 10 család 25 fajának 387 egyedét gyüjtöttük. Az egyedszámok alapján itt is a Hypogastruridae volt a domináns család, részaránya több mint 50\%. A dominancia-görbe (6. ábra) kezdeti meredeksége ellenére az összkép kiegyenlítettebb közösségi struktúrát mutat. Eudomináns faj a Ceratophysella succinea, domináns fajok a Hypogastrura socialis és Sphaeridia pumilis.

Az erdősávok mellett fontos szegélyélőhelyek a területen az árokpartok és a gyepes táblaszegélyek. Ezt bizonyítja az itt gyüjtött mintákból elökerült fajok magas száma (összesen 37 faj 2756 egyedét gyüjtöttük). Legnagyobb egyedszámmal a Tullbergiidae család volt képviselt (egyedszám szerinti részaránya közel 50\%), ez azonban az eudomináns Metaphorura denisi tömeges előfordulásának köszönhető. Utóbbi faj, valamint a szintén domináns Hypogastrura socialis magas egyedszáma miatt a dominancia-struktúra kevésbé kiegyenlített (7. ábra).

A vizsgált élőhelyek Collembola közösségeinek összehasonlítására klasszifikációs eljárásként hierarchikus agglomeratív cluster analízist végeztünk a BRAY-CURTIS index alapján. Ennek előnye más hasonlósági, fajazonossági indexekkel (JACCARD, SøRENSEN) összevetve az, hogy a mennyiségi viszonyokat is figyelembe veszi. A dendrogram (8. ábra) jól mutatja az ökotonok és a vetésterületek elkülönülését: az első nagy csoportba az erdősávok és az árokpart/táblaszegély közösségei sorolódtak, míg a második nagy csoport a három termesztett kultúrát foglalja magába.

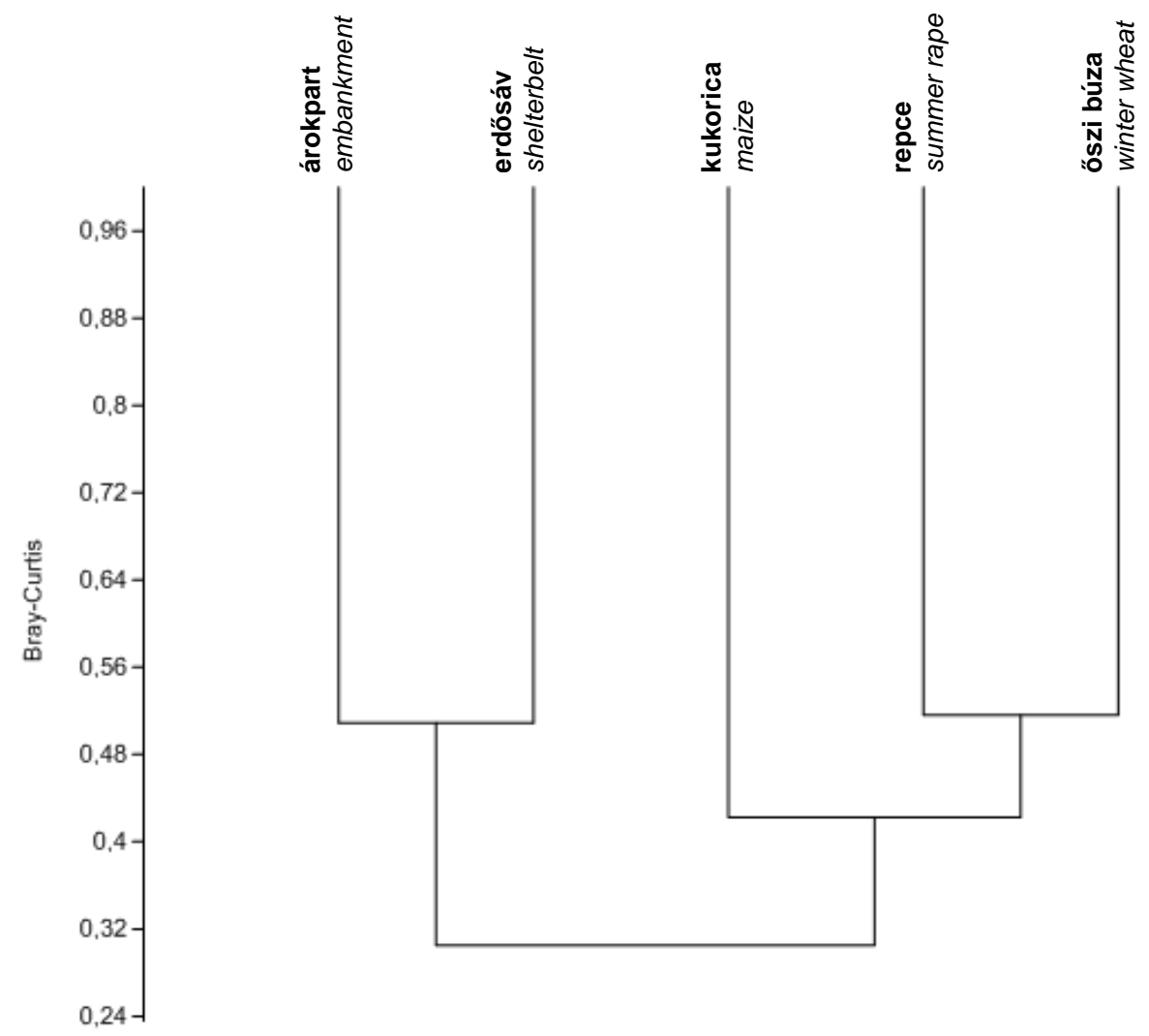

8. ábra: A BRAY-CURTIS távolságon alapuló hierarchikus cluster-analízis dendrogramja

Figure 8: Dendrogram based on cluster analysis using the BRAY-CURTIS distance measure on the Collembola communities of the sampled habitats 
A vetésterületek csoportján belül további két alcsoportot figyelhető meg. A repce és kukorica kultúrák közösségeitől - amelyek egyben a legnagyobb hasonlóságot mutatták BRAY-CURTIS módszere szerint - az őszi búza talajának magasabb fajszámú, kiegyenlített ugróvillás közössége határozott elkülönülést mutatott.

\section{KÖVETKEZTETÉSEK}

Megállapítottuk, hogy a LAJTA Project Collembola közösségeinek fajgazdagsága és egyedszáma az erdősáv és az árokpart talajában a legnagyobb. E két élőhely faunája határozottan elkülönül a mezőgazdasági táblák talajában élő ugróvillás fajoktól. Ebből arra következtetünk, hogy a Collembola közösségek kialakulásában a talaj háborítatlansága az elsődlegesen meghatározó tényező. Ugyanakkor megállapítottuk, hogy az öszi búza kultúrák Collembola diverzitása és dominancia görbéi hasonlóak az árokpartnál talált értékekhez, jelezve ezzel egy feltételezhetően létező, dinamikus kapcsolatot a mezőgazdasági táblák és az azokat szegélyező ökoton faunája között, ha a vegetáció borítottsága hasonló.

\section{IRODALOMJEGYZÉK}

Babenko, A.B., Chernova, N.M., Potapov, M.B. \& Stebaeva, M.B. (1994): Collembola of Russia and adjacent countries: Family Hypogastruridae. Nauka, Moskow. (in Russian).

BALOGH J. (1958): A talajzoológiai kutatások eredményei és feladatai hazánkban. A Magyar Tudományos Akadémia Biológiai Csoportjának Közleményei 2(1): 79-93.

BRETFELD, G. (1999): Symphypleona. In: DUNGER, W. ed.: Synopses on Palaearctic Collembola. Vol. 2. Staatliches Museum für Naturkunde, Görlitz.

DÁNYI, L. \& TRASER, GY. (2008): An annotated checklist of the springtail fauna of Hungary (Hexapoda: Collembola). Opuscula Zoologica 38: 3-82.

DEHARVENG, L. (1982): Cle de determination des genres de Neanurinae (Collembola) d'Europe et la region Mediterraneenne, avec description de deux nouveaux genres. Universite P. Sabatier. Travaux du Laboratoire d'Ecobiologie des Arthropodes Edaphiques 3(4): 7-13.

FJELlBERG, A. (1980): Identification keys to Norwegian Collembola. Norsk Entomologisk Forening.

FJellberG, A. (1998): The Collembola of Fennoscandia and Denmark. Part I.: Poduromorpha. Fauna Entomologica Scandinavica vol. 35.

Flohre, A., Rudnick, M., Traser, Gy., TscharntKea, T. \& Eggers, T. (2011): Does soil biota benefit from organic farming in complex vs. simple landscapes? http://doi.org/10.1016/j.agee.2011.02.032

Giller, K.E., Beare, M.H., Lavelle, P., IZAC, A.-M.N. \& SwIFT, M.J. (1997): Agricultural intensification, soil biodiversity and agroecosystem function. Applied Soil Ecology 6: 3-16. http://doi.org/10.1016/S0929-1393(96)00149-7

GisIN, H. (1960): Collembolenfauna Europas. Museum d'Histoire Naturelle, Genève.

Jordana, R., ARbeA, J.I. \& CARlos Simón, M.J.L. (1997): Collembola Poduromorpha. Fauna Iberica, Vol.: 8. Museo National de Ciencias Naturales, Madrid.

Massoud, Z. (1967): Monographie des Neanuridae, Collemboles Poduromorphes a piéces buccales modifiées. Centre National de la Recherche Scientifique, Paris.

Paul, D., Nongmaithem, A. \& JHA, L.K. (2011): Collembolan Density and Diversity in a Forest and an Agroecosystem. Open Journal of Soil Science 1: 54-60. http://dx.doi.org/10.4236/ojss.2011.12008

POMORSKI, J.R. (1998): Onychiurinae of Poland (Collembola: Onychiuridae). Wroclaw. pp. 201.

PotAPOW, M. (2001): Isotomidae. In: Dunger, W. ed.: Synopses on Palaearctic Collembola. Vol.: 3. Abhandlungen und Berichte des Naturkundemuseums Görlitz. Bd. 73/Nr. 2. 
Sousa, J.P., Bolger, T., Da Gama, M.M., Lukkari, T., Ponge, J-F., Simon, C., Traser, G., VAnbergen, A.J., Brennan, A., Dubs, F., IVITS, E., KeAting, A., Stofer, S. \& Watt, A. (2006): Changes in Collembola richness and diversity along a gradient of land-use intensity: a pan European study. Pedobiologia 50: 147-156. http://doi:10.1016/j.pedobi.2005.10.005

STACH, J. (1960): The Apterygotan fauna of Poland in relation to the world fauna of this group of insects. Tribe: Orchesellini. Paňstowowe Wydawnictwo Naukowe, Krakowie.

STACH, J. (1963): The Apterygotan fauna of Poland in relation to the world fauna of this group of insects. Tribe: Entomobryini. Paňstowowe Wydawnictwo Naukowe, Krakowie.

Thibaud, J.M., Shulz, H.J. \& DA GAMA, M.M. (2004): Hypogastruridae. In: Dunger, W. ed.: Synopses on Palaearctic Collembola. Vol. 4. Abhandlungen und Berichte des Naturkundemuseums Görlitz. Bd. 75/Nr. 2.

WEINER, W.M. (1996): Generic revision of Onychiurinae (Collembola: Onychiuridae) with a cladistic analysis. Annals of the Entomological Society of France (NS). 32(2): 163-200.

ZIMDARS, B. \& DUNGER, W. (1994): Tullbergiinae. In: DUNGER, W. ed.: Synopses on Palaearctic Collembola. Vol.: I. Abhandlungen und Berichte des Naturkundemuseums Görlitz. Bd. 68/Nr. 3-4. 